\title{
Seltenes Venezolanisches hämorrhagisches Fieber ausgebrochen
}

Im August kam es im venezolanischen Bundesstaat Portuguesa zu einem Ausbruch des Venezolanischen hämorrhagischen Fiebers. Innerhalb von nur 2 Wochen erkrankten 4 Personen. Eine von ihnen verstarb an den Folgen der Infektion. Der Ausbruch war auf das Dorf Banco Morrones in der Gemeinde Guaranarito beschränkt.

$\mathrm{Zu}$ den anfänglichen Symptomen des Venezolanischen hämorrhagischen Fiebers gehören Arthralgie, Fieber und Zahnfleischbluten. Später kommt es zu Krämpfen und Hämorrhagie. Die Mortalität

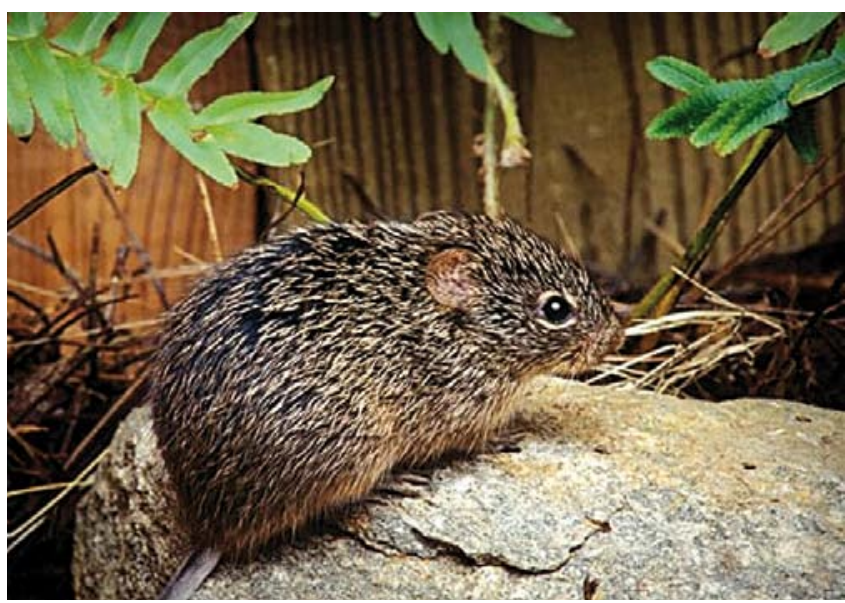

Abb. 1 Die Zuckerrohrratte (Sigmodon alstom) ist eine der bisher identifizierten Virusträger des Guanarito-Virus, die das seltene Venezolanische hämorrhagische Fieber auslösen.

Quelle: Centers for Disease Control and Prevention (CDC)/James Gathany

des Fiebers im Jahre 1989 wurden nur noch sporadisch Fälle aus den Bundesstaaten Portuguesa und Barinas gemeldet. Während der Regenzeit von Juni bis Oktober werden die meisten Fälle registriert.

Wie bei fast allen anderen Neuwelt-Arenaviren auch, sind Nagetiere das Reservoir der Erkrankung. Im Falle des Guanarito-Virus konnten bisher die Zuckerrohrratte (Sigmodon alstoni) und die Zuckermaus (Zygodontomys brevicauda) als Virusträger identifiziert werden. Die Infektion erfolgt durch Kontakt zu Ausscheidungen der Nager.

Die Krankheit, die durch das Guanarito-Virus hervorgerufen wird, wurde 1989 erstmals beschrieben. Wie andere Neuwelt-Arenaviren auch, tritt das Guanarito-Virus nur sehr selten in einem sehr kleinen Endemiegebiet auf. Kommt es zu einer humanen Infektion, ist das Mortalitätsrisiko jedoch hoch, so dass es als mögliche biologische Waffe klassifiziert wurde. Nach einem ersten größeren Ausbruch
Dr. Raymund Lösch und Dipl. Biol. Unn Klare, Bad Doberan

Quelle: promed/CDC

\section{Infektionen mit Powassan-Virus}

Seit Beginn der diesjährigen Zeckensaison infizierten sich in Minnesota/USA 2 Personen mit dem Powassan-Virus. Eine von ihnen verstarb an den Folgen. Das Virus wurde 1958 entdeckt. Seitdem gab es in Nordamerika etwa 60 Fälle - zunächst nur im Osten Kanadas und im Nordosten der USA. Seit einigen Jahren treten auch Infektionen in Michigan, Wisconsin und Minnesota auf. Die Mortalitätsrate liegt bei etwa $10 \%$.

Die ersten Symptome, die in der Regel nach 1-5 Wochen auftreten, sind Fieber, Kopfschmerzen, Erbrechen, Schwächegefühl, Sprach- und Koordinationsschwierigkeiten sowie Gedächtnisverlust. Mit Fortschreiten der Krankheit kann es zu einer Enzephalitis oder Meningitis kommen.

Das Virus wird durch 2 verschiedene Zeckenarten der Gattung Ixodes über- tragen: Die Hirschzecke (I. scapularis) ist insbesondere für die humanen Infektionen verantwortlich. Die andere Zeckenart (I. cookei) befällt fast ausschließlich kleinere Säugetiere.

Nach einem Stich durch diese Zeckenarten gelangen Krankheitserreger sehr schnell in die humane Blutbahn. Einige Untersuchungen deuten darauf hin, dass bereits 15 Minuten ausreichen könnten, um einen Menschen zu infizieren. Das ist deutlich schneller als bei anderen, durch Zecken übertragene Infektionen. So müssen Zecken bei Anaplasmose zwischen 12 und 24 Stunden und bei Borreliose sogar 24 bis 48 Stunden am Wirt saugen, um die Erreger zu übertragen.

Dr. Raymund Lösch und Dipl. Biol. Unn Klare, Bad Doberan

Quelle: promed

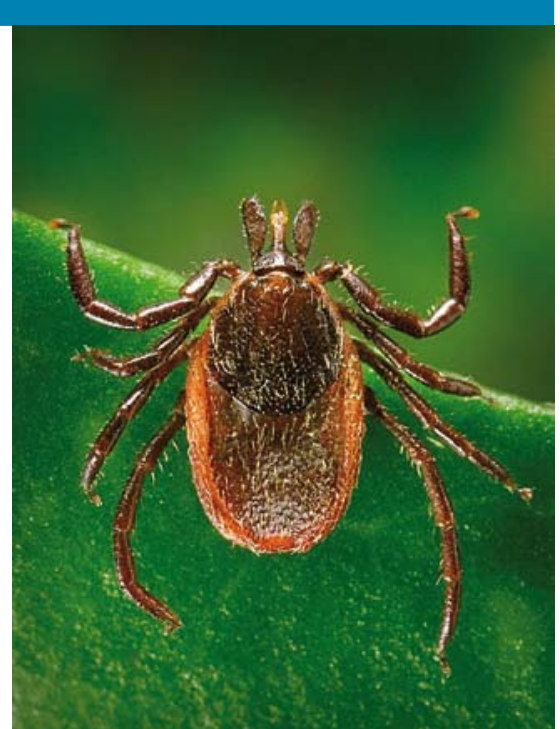

Abb. 2 Die Hirschzecke (Ixodes scapularis), auch Rehzecke oder Schwarzbeiniger Holzbock genannt, ist Hauptvektor des Powassan-Virus. Sie kann das Virus sehr schnell - möglicherweise innerhalb von Minuten - auf Menschen übertragen.

Quelle: Centers for Disease Control and Prevention (CDC)/James Gathany 
